\title{
Peritoneal amyloidosis with myopathy in primary systemic (AL) amyloidosis
}

\author{
Ali Al-Adhami, ${ }^{1}$ Kate Steiner, ${ }^{2}$ Spencer Ellis ${ }^{3}$
}

${ }^{1}$ Wirral University Teaching Hospital NHS Foundation Trust, Upton, UK

${ }^{2}$ Department of Radiology, Lister Hospital, Stevenage, UK ${ }^{3}$ Department of Rheumatology, Lister Hospital, Stevenage, UK

\section{Correspondence to}

Dr Kate Steiner,

kate.steiner@nhs.net

Accepted 26 January 2017

\section{DESCRIPTION}

We present an unusual case of primary systemic amyloidosis presenting with myopathy and peritoneal amyloid deposition. Peritoneal amyloid is a rare disease with few published cases. ${ }^{1}$

An 85-year-old man was referred to rheumatology with walking difficulties and elevation of serum creatine kinase (CK). Initial tests revealed elevated erythrocyte sedimentation rate (ESR) $76 \mathrm{~mm} /$ hour; normal C reactive protein (CRP) and serum CK of $525 \mathrm{IU} / \mathrm{L}$. Antinuclear and extractable nuclear antibodies (including anti-Jo1) were negative. Investigations for myopathy included MRI Stir sequence (figure 1) demonstrated increased signal in the hip adductors bilaterally, consistent with symmetrical myositis. CT scan of the chest, abdomen and pelvis, requested to exclude occult cancer, revealed diffuse infiltration of the mesentery and retroperitoneal fat (figure 2), despite lack of abdominal symptoms. This appearance was initially considered suspicious of malignancy without an obvious primary lesion; however, mesenteric biopsy reported only hyaline fatty sclerosis.

On follow-up, the patient described spontaneous bruising. Serum protein electrophoresis was initially normal, although urine for Bence-Jones protein showed Lambda light chain of $0.03 \mathrm{~g} / 24$ hours. The possibility of amyloidosis was considered, and

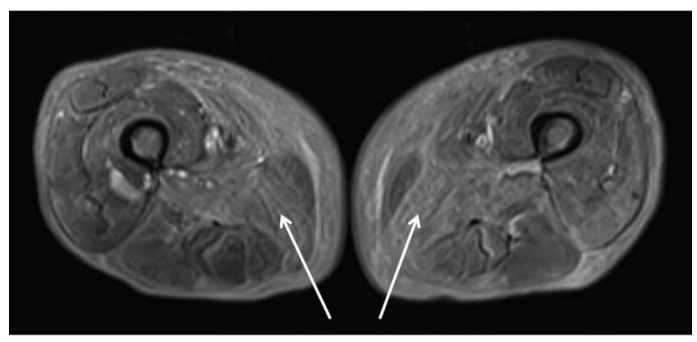

Figure 1 Axial stir MRI of both thighs demonstrating increased signal within the hip adductors (white arrows) in keeping with a diffuse symmetrical myositis.

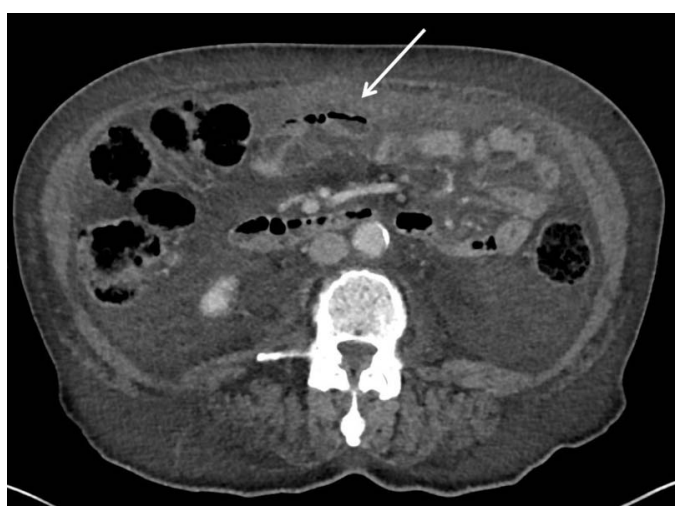

Figure 2 Axial CT image demonstrating diffuse mesenteric thickening/infiltration (white arrow).
Congo Red stain of the existing mesenteric biopsy was requested, which was positive.

Bone marrow biopsy showed 15\% plasma cells, and serum analysis demonstrated raised free light Lambda chain of $102 \mathrm{mg} / \mathrm{L}$. The final diagnosis was systemic AL (lambda-type) amyloidosis, with muscle infiltration mimicking myositis.

Two patterns of peritoneal amyloid have been described on imaging; diffuse and nodular types. Our patient had the diffuse pattern of peritoneal amyloid. ${ }^{2}$

\section{Learning points}

- Amyloidosis is a multisystem disease that can present in unusual ways and with a wide range of clinical features. A high index of suspicion for the presence of abnormal plasma proteins should be maintained in any patient presenting with a combination of normal CRP and significantly raised ESR.

- Gastrointestinal tract involvement occurs in only $8 \%$ of patients with systemic $\mathrm{AL}$ amyloidosis, most frequently involving the small bowel but peritoneal involvement is much more rarely reported.

- Differentiation of peritoneal amyloidosis from infectious or malignant diseases involving the peritoneum and greater omentum is difficult, making a biopsy essential when possible.

Acknowledgements The author thanks Dr Ellis for his tremendous support to get this case published. The author likes to extend gratitude to Dr Steiner's contribution to the case. Dr Al-Adhami has participated in setting the basis for this publication.

Contributors KS provided input in relation to the images. SE has tremendously contributed to this publication by providing essential information and radiological images. AA efforts are indispensable and continuously contributed in collecting the data and writing the case, in addition to his support with previous submissions.

Competing interests None declared.

Patient consent Obtained.

Provenance and peer review Not commissioned; externally peer reviewed.

\section{REFERENCES}

Mallet $\mathrm{H}$, Humbert $\mathrm{P}$, Dupond JL, et al. Amyloid deposition in serosal membranes. Arch Intern Med 1985; 145:2264.

2 Karouli S, Haddad W, Serghini M, et al. Peritoneal amyloidosis: unusual localization of gastrointestinal amyloidosis. Clin J Gastroenterol 2011;4:198-201. 
Copyright 2017 BMJ Publishing Group. All rights reserved. For permission to reuse any of this content visit http://group.bmj.com/group/rights-licensing/permissions.

BMJ Case Report Fellows may re-use this article for personal use and teaching without any further permission.

Become a Fellow of BMJ Case Reports today and you can:

- Submit as many cases as you like

- Enjoy fast sympathetic peer review and rapid publication of accepted articles

- Access all the published articles

- Re-use any of the published material for personal use and teaching without further permission

For information on Institutional Fellowships contact consortiasales@bmjgroup.com

Visit casereports.bmj.com for more articles like this and to become a Fellow 